\title{
Analisis Kemampuan Berpikir Kritis Matematis Ditinjau dari Aspek
} Overview

\author{
Dafid Slamet Setiana ${ }^{1 *}$, Nuryadi ${ }^{2}$, \& Rusgianto Heri Santosa ${ }^{3}$ \\ ${ }^{1,3}$ Universitas Sarjanawiyata Tamansiswa, Yogyakarta, Indonesia \\ ${ }^{2}$ Universitas Mercu Buana Yogyakarta, Yogyakarta, Indonesia
}

\section{INFO ARTICLES}

Article History:

Received: 24-06-2020

Revised: 26-11-2020

Approved: 15-12-2020

Publish Online: 25-12-2020

\section{Key Words:}

Analysis; Critical Thinking; Overview;

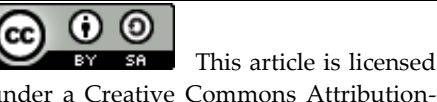
ShareAlike 4.0 International License.

\begin{abstract}
This study aims to determine students' mathematical critical thinking skills in terms of overview aspect. This research type is a quantitative descriptive study, with a population of all students of class XII from senior high schools in Pacitan Regency and the sample is 141 students which are determined by purposive sampling technique. Research data was taken through tests of critical thinking skills, questionnaires and interviews. The test result data were analyzed based on aspects of mathematical critical thinking ability (FRISCO). The results showed that students' mathematical critical thinking skills in the overview aspect were still low. These can be described as follows: (1) based on the analysis of test results, the overview aspect is included in the achievement of the lowest aspects of 72,6; (2) the results of the questionnaire analysis showed that the average percentage in the overview aspect was 58,16\% including in the medium category; (3) the interview results showed that most students only examined and checked the final result of their works.
\end{abstract}

\begin{abstract}
Abstrak: Penelitian ini bertujuan untuk mengetahui kemampuan berpikir kritis matematis siswa ditinjau dari aspek overview. Jenis penelitian ini adalah penelitian deskriptif kuantitatif, dengan populasi seluruh siswa kelas XII SMA Negeri di Kabupaten Pacitan dan sampel penelitian sebanyak 141 siswa yang ditentukan dengan teknik purposive sampling. Data penelitian diambil melalui tes kemampuan berpikir kritis, angket dan wawancara. Data hasil tes dianalisis berdasarkan aspek kemampuan berpikir kritis matematis (FRISCO). Hasil penelitian menunjukkan bahwa kemampuan berpikir kritis matematis siswa pada aspek overview masih tergolong rendah. Hal tersebut dapat dijabarkan sebagai berikut: (1) berdasarkan analisis hasil tes, aspek overview termasuk pada pencapaian aspek yang paling rendah sebesar 72,6; (2) hasil analisis angket menunjukkan persentase rata-rata pada aspek overview sebesar $58,16 \%$ termasuk pada kategori sedang; (3) hasil wawancara menunjukkan sebagian besar siswa hanya memeriksa dan mengecek pekerjaan pada hasil akhir saja.
\end{abstract}

$\begin{aligned} & \text { Correspondence } \\ & \text { dafid.setiana@ustjogja.ac.id }\end{aligned}$
Klakah,

How to Cite (APA $6^{\text {th }}$ Style): Setiana, D.S., Nuryadi, N., \& Santosa, R.H. (2020). Analisis Kemampuan Berpikir Kritis Matematis Ditinjau dari Aspek Overview. JKPM (Jurnal Kajian Pendidikan Matematika), 6(1): 1-12.

Copyright: 2020 Dafid Slamet Setiana, Nuryadi Nuryadi, Rusgianto Heri Santosa

Competing Interests Disclosures: The authors declare that they have no significant competing financial, professional or personal interests that might have influenced the performance or presentation of the work described in this manuscript. 


\section{PENDAHULUAN}

Pendidikan sebagai sebuah proses belajar memang tidak cukup dengan sekedar mengejar kecerdasannya saja. Berbagai potensi siswa atau subjek belajar lainnya juga harus mendapatkan perhatian yang proporsional agar berkembang secara optimal. Faktanya proses pembelajaran di Indonesia pada umumnya hanya diarahkan kepada kemampuan kognitif saja (Alfaiz, 2014). Siswa diwajibkan untuk menghafal informasi tanpa dituntut untuk memahami informasi yang diperolehnya (Zubaedah, 2016). Penerapan proses belajar mengajar di kelas kurang mendorong pada pencapaian kemampuan berpikir kritis (Sanjaya, 2009). Dalam pembelajaran, guru mengarahkan kepada kemampuan siswa untuk menghafal informasi, karena guru beranggapan bahwa dengan menghafal akan memudahkan siswa mendapat nilai yang baik dalam pembelajaran. Padahal keterampilan berpikir kritis merupakan salah satu modal dasar atau modal intelektual yang sangat penting bagi setiap orang dan merupakan bagian yang fundamental dari kematangan manusia. Oleh karena itu pengembangan keterampilan berpikir kritis menjadi sangat penting bagi siswa di setiap jenjang pendidikan (Lunenburg, 2011).

Seperti yang diungkapkan Wagner, bahwa terdapat tujuh survival skill yang memiliki nilai penting di era abad 21 ini, yaitu: (1) Berfikir kritis dan pemecahan masalah; (2) Kolaborasi melalui jaringan dan memimpin dengan pengaruh; (3) Lincah dan mampu menyesuaikan diri; (4) Inisiatif dan kewirausahaan; (5) komunikasi yang efektif baik tertulis maupun tidak tertulis; (6) mengakses dan menganalisis informasi; (7) imaginasi dan daya khayal. Hal senada diungkapkan oleh Kivunja (2015) yang menyatakan bahwa kompetensi yang harus dikuasi untuk menghadapi persaingan global dalam dunia kerja abad 21 adalah individu yang kreatif, berpikir kritis, mandiri, bekerja sama dengan tim, kreatifitas, informasi, komunikasi dan kemandirian belajar (Wagner, 2014).

Ennis menjelaskan berpikir kritis merupakan suatu proses yang bertujuan agar kita dapat membuat keputusan-keputusan yang masuk akal, sehingga apa yang kita anggap terbaik tentang suatu kebenaran dapat kita lakukan dengan benar (Ennis, 1996). Berpikir kritis merupakan suatu keterampilan penting yang dibutuhkan siswa untuk dapat meningkatkan kemampuan membuat penilaian sekaligus dapat menginformasikannya dengan baik, dapat menjelaskan alasan mereka dan mampu memecahkan masalah yang tidak diketahui (Facione \& Facione, 2010). Sejalan dengan pernyataan tersebut, Masek \& Yamin menyebutkan berpikir kritis adalah kemampuan untuk menganalisis dan mengevaluasi informasi serta mengajukan pertanyaan penting (Masek \& Yamin, 2012). Dengan berpikir kritis akan menghasilkan argumen dan kesimpulan yang valid, kuat dan tahan terhadap kritik.

Kemampuan berpikir kritis sangat penting bagi peserta didik di setiap jenjang pendidikan. Hal ini sesuai dengan prioritas pembangunan pendidikan yang tertera dalam kurikulum di mana peserta didik diharapkan dapat berpikir matematis, yaitu berpikir logis, analitis, sistematis, kritis, kreatif serta kemampuan bekerja sama (Lambertus, 2009). Namun faktanya secara umum kemampuan berpikir kritis siswa masih tergolong relatif rendah (Purwati, dkk., 2016; Azizah dkk., 2018).

Untuk mengatasi permasalahan rendahnya kemampuan berpikir kritis siswa, Setiana dalam penelitiannya terdahulu telah mengembangkan sebuah model pembelajaran yang dinamai model pembelajaran matematika untuk menstimulasi berpikir kritis (Setiana, dkk., 2019). Model pembelajaran telah diterapkan dalam penelitian untuk kemudian dianalisis berdasarkan aspek kemampuan berpikir kritis. Model pembelajaran tersebut memiliki beberapa tahapan, yaitu: 1) Memberikan penjelasan sederhana (elementary clarification). Berisi memfokuskan pertanyaan, menganalisis pertanyaan dan bertanya, serta menjawab pertanyaan tentang suatu penjelasan atau pernyataan; 2) Membangun keterampilan dasar (basic support). Yaitu mempertimbangkan apakah sumber dapat dipercaya atau tidak dan mempertimbangkan suatu laporan hasil observasi; 3) Menyimpulkan (inference). Yaitu kegiatan mendeduksi atau 
mempertimbangkan hasil deduksi, menginduksi atau mempertimbangkan hasil induksi, dan membuat serta menentukan nilai pertimbangan; 4) Memberikan penjelasan lanjut (advanced clarification). Yaitu mengidentifikasi istilah-istilah dan definisi pertimbangan dan juga dimensi, serta mengidentifikasi asumsi; 5) Mengatur strategi dan taktik (strategy and tactics). Yaitu menentukan tindakan dan berinteraksi dengan orang lain.

Setiana menyebutkan terjadinya berpikir kritis dalam belajar matematika adalah dengan menyajikan masalah konteks non rutin dan terbuka (open-ended) baik secara individu maupun kelompok dengan memanfaatkan pengetahuan awal siswa (Setiana dkk., 2019). Hal ini, senada dengan pendapat Romberg yang mengatakan bahwa untuk membangun berpikir kritis dalam pembelajaran siswa perlu dihadapkan pada masalah yang kontradiktif dan baru, sehingga ia mengkonstruksi pikirannya mencari kebenaran dan alasan yang jelas (Romberg, 1995).

Pembelajaran matematika dengan menggunakan model pembelajaran matematika untuk menstimulasi berpikir kritis akan membantu menstimulasi kemampuan berpikir kritis siswa. Dengan kemampuan berpikir kritis siswa akan dapat memecahkan permasalahan secara efektif (Setiana dkk., 2019). Siswa yang dapat berpikir kritis dapat melakukan evaluasi terhadap pikirannya serta membandingkan dengan data, fakta, pendapat, serta pemikiran dari orang lain.

Teori berpikir kritis yang digunakan dalam penelitian ini yaitu pengembangan berpikir kritis yang dikemukakan oleh Ennis melalui enam unsur berpikir kritis yang diakronimkan menjadi FRISCO (Focus, Reason, Inference, Situation, Clarity, dan Overview) (Ennis, 1996). Pemilihan teori ini dikarenakan aspek berpikir kritis Ennis lengkap dan memuat semua unsur yang harus ada pada kemampuan berpikir kritis. Berikut keenam aspek dan indikator berpikir kritis berdasarkan teori Ennis. Kemudian penjabaran FRISCO berdasarkan indikator berpikir kritis dalam penelitian ini disajikan dalam Tabel 1.

Tabel 1. Aspek dan Indikator Berpikir Kritis

\begin{tabular}{|c|c|}
\hline Aspek Berpikir Kritis & Indikator \\
\hline $\mathrm{F}$ (Focus) & 1. Memahami permasalahan pada soal yang diberikan. \\
\hline $\mathrm{R}$ (Reason) & $\begin{array}{l}\text { 1. Memberikan alasan berdasarkan fakta/bukti yang relevan pada setiap } \\
\text { langkah dalam membuat keputusan maupun kesimpulan }\end{array}$ \\
\hline I (Inference) & 1. Membuat kesimpulan dengan tepat. \\
\hline & $\begin{array}{l}\text { 2. Memilih reason }(\mathrm{R}) \text { yang tepat untuk mendukung kesimpulan yang } \\
\text { dibuat. }\end{array}$ \\
\hline S (Situation) & 1. Menggunakan semua informasi yang sesuai dengan permasalahan \\
\hline C (Clarity) & $\begin{array}{l}\text { 1. Menggunakan penjelasan yang lebih lanjut tentang apa yang } \\
\text { dimaksudkan dalam kesimpulan yang dibuat. } \\
\text { 2. Dapat menjelaskan istilah dalam soal }\end{array}$ \\
\hline & 3. Memberikan contoh kasus yang mirip dengan soal tersebut \\
\hline $\mathrm{O}($ Overview $)$ & $\begin{array}{l}\text { 1. Memeriksa atau mengecek kembali secara menyeluruh mulai dari } \\
\text { awal sampai akhir (yang dihasilkan FRISC) }\end{array}$ \\
\hline
\end{tabular}

\section{Sumber: Ennis, 1996}

Untuk mengetahui tingkat kemampuan berpikir kritis matematis siswa dapat dilakukan dengan berbagai cara, salah satunya dengan menganalisis kemampuan berpikir kritis siswa pada saat menyelesaikan masalah. Hal ini sesuai dengan pendapat yang dikemukakan oleh Johnson bahwa ada hubungan antara berpikir kritis dengan cara menyelesaikan masalah (Johnson, 2009).

Berdasarkan hasil observasi yang telah dilaksanakan, dalam menyelesaikan soal cerita, sekitar 50\% siswa tidak mengecek kembali hasil pekerjaan mereka. setelah menyelesaikan masalah, siswa cenderung puas dengan hasil kerjanya dan malas untuk memeriksa kembali. Hal ini mengindikasikan bahwa 
kemampuan berpikir kritis siswa pada aspek overview belum sesuai dengan tujuan yang diharapkan. Aspek overview menekankan aktivitas memeriksa atau mengecek kembali secara menyeluruh mulai dari awal sampai akhir penyelesaian masalah. Langkah ini penting dilakukan untuk mengecek apakah hasil penyelesaian soal sudah sesuai dengan ketentuan dan tidak terjadi kontradiksi dengan pertanyaan/permasalahan yang diberikan. Kondisi inilah yang membuat peneliti memilih aspek overview dari enam aspek berpikir kritis yang dipaparkan oleh Ennis (Ennis, 2011).

Untuk memperkuat hasil observasi, peneliti melakukan prariset berupa pemberian soal tes kepada 10 siswa dari SMAN 2 Pacitan berdasarkan rekomendasi guru matematika di sekolah tersebut. Secara keseluruhan ditinjau dari aspek overview, sebagian besar siswa dalam pengerjaan soal tes hanya menyelesaikan persoalan yang diberikan dan langsung menyampikan hasil pekerjaannya kepada peneliti tanpa mengecek atau memeriksa ulang hasil pekerjaan mereka. Hanya ada 4 siswa yang terlihat mengecek hasil pekerjaan secara singkat. Berdasarkan hal tersebut, peneliti mengasumsikan bahwa kesepuluh siswa tersebut masih belum memenuhi indikator kemampuan berpikir kritis pada aspek overview yaitu memeriksa atau mengecek kembali secara menyeluruh hasil penyelesaian masalah mulai dari awal sampai akhir.

Penelitian yang berkaitan dengan analisis kemampuan berpikir kritis siswa sudah banyak dilakukan. Cahyono (2017) berusaha menganalisis keterampilan berpikir kritis ditinjau dari perbedaan gender, di mana terdapat perbedaan keterampilan berpikir kritis pada mahasiswa perempuan dan laki-laki. Priyadi dkk (2018) menganalisis kemampuan berpikir kritis siswa SMA dengan hasil analisis kemampuan berpikir kritis pada kategori rendah. Widodo dkk. (2019) dalam penelitiannya menunjukkan bahwa sampel penelitian memenuhi setiap indikator berpikir kritis pada langkah pemecahan masalah, sehingga dapat dikatakan memiliki kemampuan berpikir kritis tingkat tinggi. Relatif banyak penelitian terkait analisis kemampuan berpikir kritis, namun belum ada penelitian yang berfokus pada aspek overview, untuk itu perlu dilakukan kajian analisis terkait analisis kemampuan berpikir kritis siswa khususnya pada aspek overview untuk melengkapi penelitian-penelitian terdahulu.

Adanya ketimpangan antara apa yang diharapkan dengan fakta yang terjadi di lapangan atau pada pembelajaran di kelas berkaitan dengan kemampuan berpikir kritis medorong peneliti untuk melakukan penelitian "Analisis Kemampuan Berpikir Kritis Matematis Ditinjau dari Aspek Overview". Adapun rumusan masalah dari penelitian ini yaitu bagaimana kemampuan berpikir kritis matematis siswa ditinjau dari aspek overview? Berdasarkan rumusan masalah tersebut, ditentukan tujuan penelitian yaitu untuk mengetahui kemampuan berpikir kritis matematis siswa ditinjau dari aspek overview.

\section{METODE}

Penelitian ini merupakan penelitian deskriptif kuantitatif. Metode deskriptif kuantitatif untuk menggambarkan kondisi pembelajaran terutama keadaan penguasaan kemampuan berpikir kritis matematis siswa yang diukur melalui angka kemudian dideskripsikan. Penelitian ini merupakan penelitian lanjutan setelah penerapan model pembelajaran untuk menstimulasi berpikir kritis. Penelitian ini dilaksanakan di enam SMA negeri di Kabupaten Pacitan dari bulan November 2016 sampai Januari 2017. Keenam SMA tersebut yaitu SMA N 2 Pacitan, SMA N Punung, SMA N Tulakan, SMA N 1 Ngadirojo, SMA N 2 Ngadirojo, dan SMA N Tegalombo. Populasi dalam penelitian ini yaitu seluruh siswa kelas XII di 6 SMA negeri di Kabupaten Pacitan semester ganjil tahun pelajaran 2016/2017 sebanyak 988 siswa. Sampel pada penelitian ini yaitu masing-masing satu kelas XII IPA dari enam SMA negeri di Kabupaten Pacitan yang keseluruhannya sebanyak 141 siswa. Sampel dipilih dengan teknik purposive sampling, berdasarkan hasil penelitian sebelumnya dengan sampel yang sama telah dilakukan uji homogenitas terhadap hasil pretes. Hasil uji homogenitas dengan bantuan SPSS dituangkan dalam Tabel 2., 
Tabel 2. Hasil Uji Homogenitas

\begin{tabular}{llll} 
Levene Statistic & $\mathrm{df}_{1}$ & $\mathrm{df}_{2}$ & Sig. \\
\hline, 715 & 5 & 135 &, 613 \\
\hline
\end{tabular}

Sumber: Diolah dari data penelitian, 2017

Berdasarkan Tabel 2. dapat diketahui nilai signifikansi sebesar 0,613. Karena nilai Sig. 0,613 > 0,05, maka dapat disimpulkan data memiliki variansi yang homogen.

Pengambilan data menggunakan teknik tes, angket dan wawancara. Teknik tes berupa tes kemampuan berpikir kritis matematis. Berdasarkan teknik pengambilan data tersebut, maka instrumen penelitian yang digunakan adalah instrumen tes, lembar angket berpikir kritis, dan pedoman wawancara tidak terstruktur. Instrumen tes berupa soal essay dengan soal tes yang bersifat open-ended sebanyak 5 butir. Soal-soal yang digunakan dalam tes ini yaitu pada materi Transformasi Geometri. Lembar angket digunakan untuk mengukur persentase pencapaian siswa pada setiap aspek berpikir kritis. angket terdiri dari 18 pernyataan dengan pilihan jawaban "ya" atau "tidak". Lembar wawancara digunakan untuk memverifikasi hasil jawaban siswa dari aspek berpikir kritis overview. Hasil tes kemudian dianalisis berdasarkan aspek berpikir kritis secara matematis. Pada analisis ini nilai siswa dikelompokkan sesuai aspek dan indikator berpikir kritis. Adapun diantara enam aspek berpikir kritis yang dikemukakan Ennis (2011) berupa FRISCO, akan dilakukan analisis terhadap aspek overview. Adapun kriteria aspek kemampuan berpikir kritis siswa dituangkan dalam Tabel 3.

Tabel 3. Kriteria Kemampuan Berpikir Kritis

\begin{tabular}{cc}
\hline Persentase $(\%)$ & Kriteria \\
\hline $80,0<\bar{M} \leq 100,0$ & Sangat tinggi \\
$60,0<\bar{M} \leq 80,0$ & Tinggi \\
$40,0<\bar{M} \leq 60,0$ & Sedang \\
$20,0<\bar{M} \leq 40,0$ & Rendah \\
$0,0 \leq \bar{M} \leq 20,0$ & Sangat rendah \\
\hline
\end{tabular}

\section{HASIL}

1. Analisis kemampuan berpikir kritis ditinjau dari aspek berpikir kritis matematis

Analisis hasil tes dilakukan berdasarkan aspek kemampuan berpikir kritis. Hasil analisis untuk setiap aspek dituangkan dalam bentuk tabel dan grafik yang dapat dilihat pada Tabel 4. dan Gambar 1 .

Tabel 4. Analisis Hasil Tes Berdasarkan Aspek Berpikir Kritis

\begin{tabular}{ccc}
\hline Aspek & Rata-rata Nilai & Kriteria \\
\hline F (Focus) & 91,2 & Sangat Tinggi \\
R (Reason) & 82,9 & Sangat Tinggi \\
I (Inference) & 78,5 & Tinggi \\
S (Situation) & 94,7 & Sangat Tinggi \\
C (Clarity) & 87,3 & Sangat Tinggi \\
O (Overview) & 72,6 & Tinggi \\
\hline
\end{tabular}




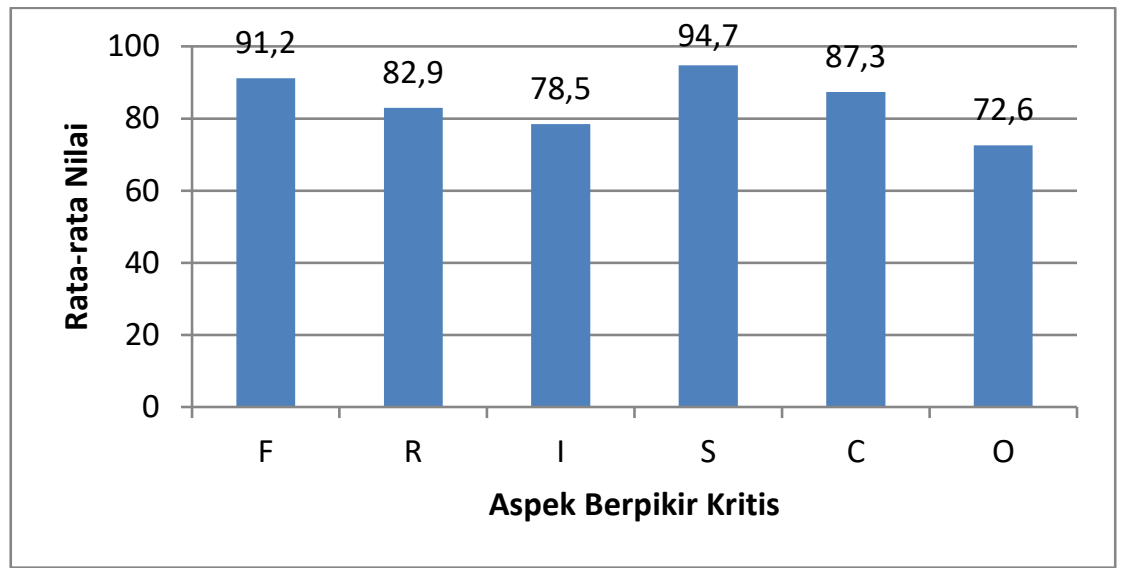

Gambar 1. Hasil Tes Berdasarkan Aspek Berpikir Kritis

Informasi yang didapatkan berdasarkan Tabel 4. yaitu rata-rata nilai pada aspek $\mathrm{F}$ (Focus) sebesar 91,2; aspek R (Reason) sebesar 82,9; aspek I (Inference) sebesar 78,5; aspek S (Situation) sebesar 94,7; aspek C (Clarity) sebesar 87,3; dan aspek O (Overview) sebesar 72,6. Berdasarkan hasil tersebut dapat diketahui aspek $\mathrm{O}$ (Overview) memiliki nilai terendah.

2. Analisis kemampuan berpikir kritis berdasarkan angket

Analisis menggunakan angket berpikir kritis dituangkan dalam bentuk tabel dan grafik yang dapat dilihat pada Tabel 5. dan Gambar 2.

Tabel 5. Analisis Angket Berdasarkan Aspek Berpikir Kritis

\begin{tabular}{ccc}
\hline Aspek & Persentase Banyaknya Siswa & Kriteria \\
\hline $\mathrm{F}($ Focus $)$ & $83,67 \%$ & Sangat Tinggi \\
\hline $\mathrm{R}($ Reason $)$ & $72,93 \%$ & Tinggi \\
\hline $\mathrm{I}$ (Inference $)$ & $85,65 \%$ & Sangat Tinggi \\
\hline $\mathrm{S}$ (Situation) & $91,28 \%$ & Sangat Tinggi \\
\hline $\mathrm{C}($ Clarity $)$ & $68,71 \%$ & Tinggi \\
\hline $\mathrm{O}($ Overview $)$ & $58,16 \%$ & Sedang \\
\hline
\end{tabular}

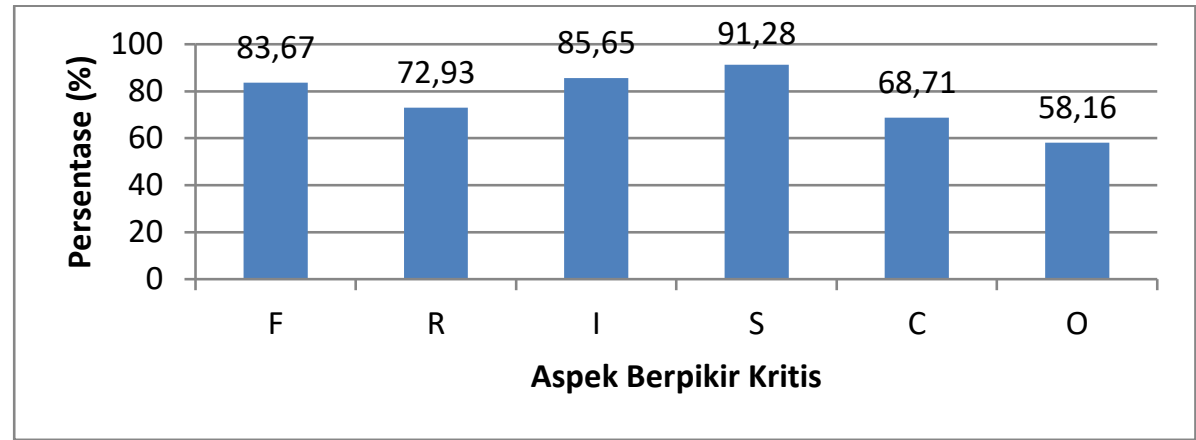

Gambar 2. Hasil Angket Berdasarkan Indikator Berpikir Kritis

Berdasarkan Tabel 5. dan Gambar 2. tampak aspek O (Overview) memiliki persentase paling rendah dibandingkan aspek yang lain yaitu 58,16\% dan berada pada kategori sedang. Dengan demikian dapat dikatakan sebanyak 41,84\% siswa tidak memeriksa atau mengecek kembali secara menyeluruh hasil penyelesaian masalah mereka mulai dari awal sampai akhir. Untuk menganalisis lebih mendalam 
terkait aspek overview, dilakukan analisis terhadap pernyataan angket pada aspek overview, hasilnya tertuang pada Tabel 6 .

\begin{tabular}{cllll}
\multicolumn{6}{c}{ Tabel 6. Analisis Angket Berdasarkan Aspek } & Overview pada Kemampuan Berpikir Kritis \\
\hline No & Pernyataan & $\begin{array}{l}\text { Banyaknya } \\
\text { Siswa }\end{array}$ & Persentase & Kriteria \\
\hline 1 & $\begin{array}{l}\text { Saya memeriksa dan mengecek hasil } \\
\text { pekerjaan secara sekilas }\end{array}$ & 78 & $55,32 \%$ & Sedang \\
2 & $\begin{array}{l}\text { Saya hanya memeriksa dan mengecek } \\
\text { hasil akhir/kesimpulan dari pekerjaan } \\
\text { saya }\end{array}$ & 112 & $79,43 \%$ & Tinggi \\
3 & $\begin{array}{l}\text { Saya memeriksa dan mengecek } \\
\text { pekerjaan saya dari awal sampai akhir } \\
\text { Rata-rata }\end{array}$ & 56 & $39,72 \%$ & Rendah \\
\end{tabular}

Berdasarkan Tabel 6., diperoleh bahwa pada pernyataan angket memeriksa dan mengecek hasil pekerjaan secara sekilas tergolong dalam kategori sedang dengan banyaknya siswa yang melakukan aktivitas tersebut sebanyak 78 siswa dengan persentase sebesar 55,32 \%. Pada pernyataan angket memeriksa dan mengecek hasil akhir/kesimpulan dari pekerjaan tergolong dalam kategori tinggi dengan banyaknya siswa yang melakukan aktivitas tersebut sebanyak 112 siswa dengan persentase sebesar $79,43 \%$. Pada pernyataan angket memeriksa dan mengecek pekerjaan dari awal sampai akhir tergolong dalam kategori rendah dengan banyaknya siswa yang melakukan aktivitas tersebut sebanyak 56 siswa dengan persentase sebesar 39,72\%. Secara keseluruhan, aspek overview pada kemampuan berpikir kritis siswa masih tergolong sedang dengan rata-rata persentase pencapaian 58,16. Dari tiga pernyataan tersebut, pencapaian tertinggi berada pada pernyataan angket memeriksa dan mengecek hasil akhir/kesimpulan dari pekerjaan. Sedangkan pencapaian terendah pada pernyataan angket memeriksa dan mengecek pekerjaan dari awal sampai akhir.

3. Analisis kemampuan berpikir kritis berdasarkan wawancara

Wawancara bertujuan untuk memverifikasi hasil jawaban siswa dari aspek berpikir kritis overview. Karena berdasarkan uji homogenitas menunjukkan bahwa varian data yang homogen, maka setiap sampel memiliki peluang yang sama untuk menjadi sampel pada tahap wawancara. Dengan demikian sampel wawancara dipilih secara acak terhadap lima siswa dari 6 sekolah lokasi penelitian yaitu 2 siswa dari SMA N 2 Pacitan, 1 siswa dari SMA N Punung, dan 2 siswa dari SMA N 1 Ngadirojo. Dari kelima siswa tersebut diperoleh gambaran mengenai aktivitas siswa dalam memeriksa dan mengecek hasil pekerjaan mereka. Adapun gambaran aspek overview dari kelima siswa yaitu Responden S1 memeriksa dan mengecek pekerjaan dari awal sampai akhir, Responden S2, S3, dan S5 hanya memeriksa dan mengecek hasil akhir/kesimpulan dari pekerjaan, sedangkan Responden S4 memeriksa dan mengecek hasil pekerjaan secara sekilas. Hasil tersebut menunjukkan lebih banyak siswa yang tidak melakukan aktivitas memeriksa dan mengecek pekerjaan dari awal sampai akhir. Dengan demikian menunjukkan bahwa aspek overview pada kemampuan berpikir kritis siswa belum terpenuhi. 


\section{PEMBAHASAN}

Penelitian ini bertujuan untuk menganalisis kemampuan berpikir kritis matematis siswa ditinjau dari aspek overview. Kemampuan yang dimaksud dalam penelitian ini dikhususkan pada kemampuan memeriksa dan mengecek kembali secara menyeluruh jawaban dari awal sampai akhir. Dengan melakukan tahap pengecekan atau pemeriksaan kembali hasil pekerjaan, bermanfaat untuk memastikan jawaban tersebut benar. Langkah ini juga akan menentukan apakah hasil penyelesaian yang kita dapatkan dapat diterima sebagai penyelesaian masalah, atau dilakukan penyelesaian kembali karena terdapat beberapa hal yang keliru sehingga jawabannya tidak dapat dipertanggungjawabkan (Juniarti \& Renda, 2019).

Hasil analisis tes kemampuan berpikir kritis menunjukkan aspek overview berada pada pencapaian yang paling rendah. Meskipun masih dalam kategori tinggi, namun dibandingkan aspek lainnya termasuk jauh di bawahnya. Penerapan model pembelajaran matematika untuk menstimulasi berpikir kritis sebelum pelaksanaan tes telah sedikit menaikkan pencapaian siswa dibandingkan pada tahap pra penelitian, namun hasil akhir pada aspek ini masih belum sesuai dengan yang diharapkan.

Untuk mengukur aspek overview pada hasil tes, dapat dilihat dari kemampuan siswa dalam memeriksa ulang hasil penyelesaian masalah. Jika pada jawaban terdapat kesalahan penulisan maupun kesalahan konsep namun tetap terdapat hasil akhir atau kesimpulan, maka hal tersebut menandakan siswa tidak melakukan pengecekan atau memeriksa ulang hasil pekerjaan. Terlebih pada penyelesaian soal dengan metode gambar, jika terdapat kesalahan penulisan dan kurang lengkap dalam memberi keterangan gambar, hal tersebut dapat dikatakan bahwa siswa tidak melakukan peninjauan ulang atau mengoreksi kembali jawaban dan gambar yang telah dibuat. Sebaliknya, pada jawaban yang lengkap atau bahkan ada jawaban yang terdapat perbaikan di dalamnya sehingga jawaban menjadi lengkap, menandakan bahwa siswa melakukan pengecekan terhadap jawaban yang dituliskan. Gambar 3. merupakan contoh jawaban siswa berkaitan dengan pengecekan atau pemeriksaan ulang hasil pekerjaan.
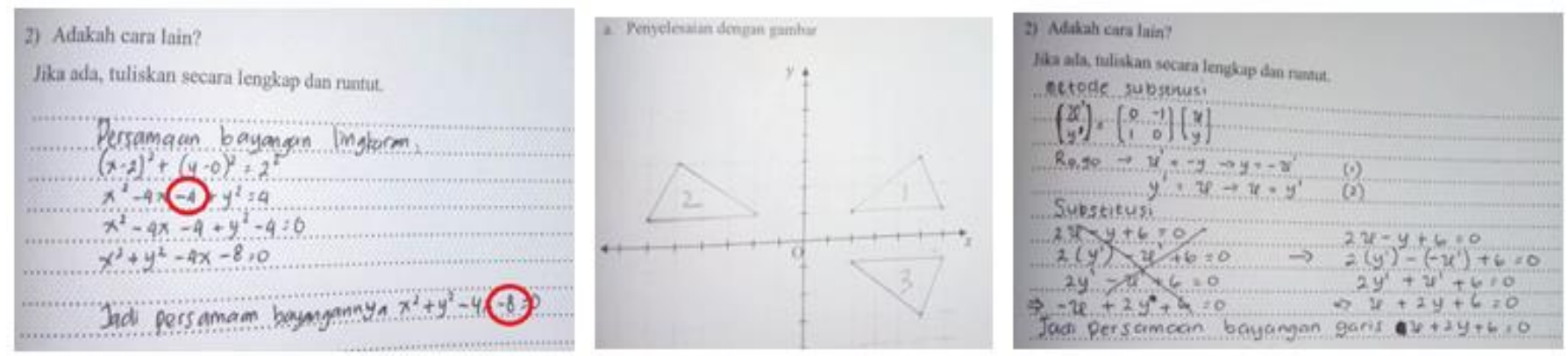

\section{Gambar 3. Contoh Hasil Jawaban Siswa}

Hasil analisis angket menunjukkan rata-rata persentase aspek overview termasuk dalam kategori sedang. Pernyataan angket pada aspek overview yaitu memeriksa dan mengecek hasil pekerjaan secara sekilas, memeriksa dan mengecek hasil akhir/kesimpulan dari pekerjaan, dan memeriksa dan mengecek pekerjaan dari awal sampai akhir. Dari ketiga pernyataan tersebut, siswa paling banyak melakukan aktivitas memeriksa dan mengecek hasil akhir/kesimpulan dari pekerjaan. Padahal aspek overview mengacu pada kemampuan memeriksa atau mengecek kembali mulai dari permasalahan, langkah tiap pengerjaan sampai dengan hasil akhir (yang dihasilkan dari aspek FRISC). Hasil ini sesuai dengan temuan Fridanianti dkk. (2018) yang menyebutkan subjek belum dapat memenuhi kriteria Overview karena subjek setelah selesai menggerjakan hanya mengecek kembali hasil akhir. Hasil serupa juga disebutkan oleh Affandy dkk. (2019), dalam temuannya disebutkan capaian aspek overview berada pada kategori rendah dikarenakan siswa tidak memeriksa ulang langkah pengerjaan secara lengkap. Widodo dkk. (2019) juga mendukung temuan yang 
ada, di mana hasil temuannya menyebutkan siswa kurang memiliki karakter reason dan overview untuk kemampuan berpikir kritis.

Analisis hasil wawancara menunjukkan hal yang tidak jauh berbeda. Dari lima siswa yang dipilih berdasarkan rekomendasi dari guru, sebanyak tiga siswa mengatakan bahwa mereka memeriksa atau mengecek pekerjaan mereka pada hasil akhir atau kesimpulan saja. Berdasarkan hasil wawancara mendalam, alasan mereka secara umum yaitu mereka malas dan tidak memiliki cukup waktu untuk mengecek jawaban secara keseluruhan. Mereka berasumsi bahwa hasil akhir atau kesimpulan telah mewakili hasil pekerjaan secara keseluruhan, sehingga dengan meninjau hasil akhir atau kesimpulan sama artinya dengan meninjau hasil penyelesaian masalah secara keseluruhan. Satu siswa diantara kelima siswa yang telah diwawancara mengatakan bahwa siswa tersebut memeriksa atau mengecek hasil pekerjaan secara sekilas. Ia hanya mengecek dan memastikan secara sekilas apakah pada setiap nomor sudah berisi jawaban atau belum tanpa mengecek atau membaca apa yang telah ditulis. Ia tidak memeriksa apakah jawaban yang ditulis sudah benar atau belum, terdapat kesalahan penulisan atau tidak, bahkan terdapat kesimpulan atau belum. Alasan siswa memilih cara mengecek hasil pekerjaan yang demikian adalah siswa tersebut malas untuk melakukan pengecekan ulang dan tidak peduli dengan nilai yang akan diperoleh. Dari kelima siswa responden wawancara, hanya satu siswa yang melakukan pengecekan hasil pekerjaan secara menyeluruh dari awal sampai akhir. Siswa tersebut termasuk siswa yang teliti dan cukup berprestasi berdasarkan informasi dari guru matematika. Alasan siswa melakukan pengecekan hasil pekerjaan secara menyeluruh adalah ia ingin memastikan bahwa jawaban yang telah ia tulis sudah benar, lengkap, dan tidak terdapat kesalahan perhitungan maupun penulisan. Jika siswa telah memeriksa step by step tahapan penyelesaian mulai dari rumus yang digunakan, perhitungan yang dilakukan hingga penyusunan kesimpulan dengan runtut dan tidak terdapat kesalahan, dapat dipastikan jawaban yang dituliskannya mendekati $100 \%$ benar. Hal tersebut sejalan dengan langkah pemecahan masalah Polya pada aspek looking back (Polya, 2004), di mana tahap ini dilakukan dengan mencari kemungkinan adanya generalisasi, melakukan pengecekan terhadap hasil yang diperoleh, mencari cara lain untuk meyelesaikan masalah yang sama, mencari kemungkinan adanya penyelesaian lain, dan menelaah kembali proses penyelesaian masalah yang telah dibuat (Wahyu dkk., 2019). Di samping menelaah konsep dan tahapan penyelesaian soal, siswa mengaku pada saat memeriksa jawaban soal tes yang diberikan menemukan beberapa kesalahan penulisan dan langsung diperbaiki. Meskipun bukan kesalahan pada konsep namun siswa tersebut puas dengan hasil pekerjaan yang dinilainya tuntas.

Hasil wawancara mendalam tersebut menguatkan hasil analisis tes dan angket yang menunjukkan bahwa sebagian besar siswa tidak memenuhi aspek overview dalam berpikir kritis. Siswa cenderung tidak memeriksa kembali hasil penyelesaian masalah secara menyeluruh. Adapun beberapa faktor yang menyebabkan kendala tersebut yaitu: (1) kurangya motivasi siswa dalam menyelesaiakan soal atau dengan kata lain siswa cenderung malas memeriksa ulang, (2) siswa terlalu percaya diri dengan jawaban yang telah diselesaikan sehingga menganggap jawaban yang telah ditulis pasti benar, (3) siswa tidak memiliki banyak waktu untuk memeriksa hasil jawaban dari awal hingga akhir.

Berdasarkan analisis hasil tes kemampuan berpikir kritis, analisis angket, dan analisis hasil wawancara, secara umum diketahui bahwa kemampuan berpikir kritis siswa pada aspek overview di enam SMA negeri se Kabupaten Pacitan masih kurang sesuai dengan yang diharapkan. Berdasarkan hal tersebut dapat dikatakan bahwa siswa masih belum mampu melaksanakan aktivitas memeriksa dan mengecek kembali hasil pekerjaan mereka secara menyeluruh dari awal hingga akhir sehingga menunjukkan bahwa kemampuan berpikir kritis siswa khususnya pada aspek overview masih rendah.

Fakta tersebut berbanding terbalik dengan pemikiran Ennis (2011) bahwa salah satu komponen berpikir kritis adalah overview. Siswa yang memiliki kemampuan berpikir kritis harus mampu menguasai keenam aspek berpikir kritis yaitu FRISCO (Focus, Reason, Inference, Situation, Clarity, dan Overview) 
secara menyeluruh. Semua aspek memiliki perannya masing-masing dalam memberikan kontribusi kemampuan berpikir kritis, sehingga setiap aspek sangat penting untuk dimiliki siswa atau peserta didik.

Pentingnya meninjau ulang jawaban pada aspek overview sesuai dengan tahapan pemecahan masalah menurut Polya yaitu melihat kembali (looking back). Looking back menjadi langkah penentu bagi kebenaran problem solving yang dilakukan (Argarini, 2018). Hal ini senada dengan temuan Leong dkk. (2012) yang mengemukakan bahwa ketercapaian pembelajaran model pemecahan masalah Polya terindikasi dari kesuksesan dalam looking back. Looking Back menjadi langkah penting karena tidak hanya sekedar memeriksa kebenaran langkah solusi, tetapi termasuk juga pertimbangan solusi alternatif dan representasinya, menemukan strategi yang lebih efisien, dan penggunaan proses atau cara penyelesaian untuk masalah terkait lainnya. Sehingga siswa yang melakukan tahap looking back yang baik secara otomatis memiliki kemampuan yang baik pula dalam tahap penyelesaian masalah lainnya (Herlita dkk., 2018). Dengan demikian siswa yang menyelesaikan masalah dengan diakhiri langkah memeriksa ulang jawaban dari awal hingga akhir dapat dikatakan dapat memastikan kebenaran penyelesaian masalah tersebut.

Hasil temuan dari penelitian ini sejalan dengan temuan Fridanianti dkk. (2018), dari keempat subjek penelitian, terdapat dua subjek dengan gaya kognitif impulsif yang tidak menunjukkan aspek overview. Penelitian serupa juga dilakukan oleh Widodo dkk. (2019) berkaitan dengan analisis kemampuan berpikir kritis yang menunjukkan dari dua subjek penelitian, satu diantaranya tidak selalu mengecek apa yang telah disimpulkan, atau dengan kata lain salah satu subjek tidak memenuhi aspek overview.

\section{SIMPULAN}

Berdasarkan penelitian yang telah dilakukan maka dapat disimpulkan bahwa kemampuan berpikir kritis matematis siswa pada aspek overview masih tergolong rendah. Hal tersebut didapat dari beberapa analisis, yaitu analisis berdasarkan hasil tes ditinjau dari aspek kemampuan berpikir kritis FRISCO, aspek $\mathrm{O}$ (overview) termasuk pada pencapaian yang paling rendah meskipun berada pada kategori tinggi dengan pencapaian nilai 72,6 . Hasil analisis berdasarkan angket menunjukkan rata-rata pencapaian siswa pada aspek overview sebesar 58,16\% termasuk pada kategori sedang. Sebesar 79,43\% siswa hanya melakukan aktivitas memeriksa dan mengecek pekerjaan pada hasil akhir/kesimpulannya saja, sedangkan pengecekan secara keseluruhan dari awal hingga akhir pekerjaan hanya sebesar 39,72\%. Hasil analisis berdasarkan wawancara siswa juga menunjukkan sebagian besar siswa hanya memeriksa dan mengecek pekerjaan pada hasil akhir/kesimpulannya saja.

Dengan kondisi aspek overview yang masih rendah atau tidak terpenuhi sesuai dengan yang diharapkan, dimungkinkan untuk adanya penelitian lanjutan berkaitan dengan upaya peningkatan aspek berpikir kritis overview. Aspek overview yang mengharuskan siswa mengecek atau memeriksa kembali hasil pekerjaan secara menyeluruh dari awal sampai akhir merupakan aspek yang cukup penting. Dengan melakukan tahap pengecekan atau pemeriksaan kembali hasil pekerjaan, bermanfaat untuk memastikan jawaban tersebut benar. Untuk itu guru sebagai pihak yang berhadapan langsung dengan peserta didik hendaknya senantiasa mengingatkan akan pentingnya memeriksa kembali hasil pekerjaan setiap kali memberikan permasalahan atau soal kepada siswa. 


\section{UCAPAN TERIMA KASIH}

Ucapan terimakasih peneliti sampaikan kepada pihak sekolah SMA N 2 Pacitan, SMA N Punung, SMA N Tulakan, SMA N 1 Ngadirojo, SMA N 2 Ngadirojo, dan SMA N Tegalombo atas kesempatan yang diberikan untuk melaksanakan penelitian. Bapak Prof. Dr. Rusgianto Heri Santosa, M.Pd dan Ibu Dr. Rita Eka Izzaty, S.Psi., M.Si atas bimbingan dan masukannya, dan semua pihak yang telah berkontribusi dalam penelitian ini.

\section{DAFTAR RUJUKAN}

Affandy, H., Aminah, N. S., \& Supriyanto, A. (2019). Analisis Keterampilan Berpikir Kritis Siswa Pada Materi Fluida Dinamis Di SMA Batik 2 Surakarta. Jurnal Materi Dan Pembelajaran Fisika (JMPF), 9(1), 25-33. https://jurnal.uns.ac.id/jmpf/article/view/31608

Alfaiz. (2014). Pembelajaran Afektif Merupakan Salah Satu Strategi Dalam Pembentukan Karakter Peserta Didik (Sebuah Tinjauan Dari Perspektif Psikologi; Social Cognitive Theory). Jurnal Pelangi, 7(1), 8596. https://doi.org/10.22202/jp.2014.v7i1.152

Argarini, D. F. (2018). Analisis Pemecahan Masalah Berbasis Polya pada Materi Perkalian Vektor Ditinjau dari Gaya Belajar. Matematika dan Pembelajaran, 6(1), 91-99. https://doi.org/10.33477/mp.v6i1.448

Azizah, M., Sulianto, J., \& Cintang, N. (2018). Analisis Keterampilan Berpikir Kritis Siswa Sekolah Dasar Pada Pembelajaran Matematika Kurikulum 2013. Jurnal Penelitian Pendidikan, 35(1), 61-70.

Cahyono, B. (2017). Analisis Ketrampilan Berfikir Kritis Dalam Memecahkan Masalah Ditinjau Perbedaan Gender. AKSIOMA, 8(1), 50-64. https://doi.org/10.26877/aks.v8i1.1510

Ennis, R. H. (1996). Critical thinking. Prentice Hall, Inc.

Ennis, R. H. (2011). The nature of critical thinking: An outline of critical thinking dispositions and abilities. Presentation at the Sixth International Conference on Thinking at MIT, Cambridge, MA, July, 1994. Faculty.Education.Illinois.Edu, 1-8.

Facione, N. C., \& Facione, P. A. (2010). Externalizing the critical thinking in knowledge development and clinical judgment. Nursing Outlook, 44(3), 129-136. https://doi.org/10.1016/S0029-6554(06)80005-9

Fridanianti, A., Purwati, H., \& Murtianto, Y. H. (2018). Analisis Kemampuan Berpikir Kritis Dalam Menyelesaikan Soal Aljabar Kelas VII SMP N 2 Pangkah Ditinjau Dari Gaya Kognitif Reflektif Dan Kognitif Impulsif. AKSIOMA : Jurnal Matematika Dan Pendidikan Matematika, 9(1), 11-20. https://doi.org/10.26877/aks.v9i1.2221

Herlita, Sugiatno, \& Dian. (2018). Potensi Looking Back Siswa Dalam Menyelesaikan Soal Materi Barisan Dan Deret Aritmetika di SMA. Jurnal Pendidikan Dan Pembelajaran Khatulistiwa, 7(9), 1-8. https://jurnal.untan.ac.id/index.php/jpdpb/article/view/28180/75676578288

Johnson, E. B. (2009). Contextual teaching \& learning. In Mizan Media Utama. Mizan Media Utama.

Juniarti, N. D., \& Renda, N. T. (2019). Penerapan Model Problem Solving Untuk Meningkatkan Hasil Belajar Matematika. Jurnal Ilmiah Pendidikan Profesi Guru, 2(3), 248-257. https://doi.org/10.23887/jippg.v2i3.14289

Lambertus. (2009). Pentingnya Melatih Keterampilan Berpikir Kritis Dalam Pembelajaran Matematika Di SD. Forum Pendidikan, 28(2), 136-142.

Leong, Y. H., Toh, T. L., Tay, E. G., Quek, K. S., \& Dindyal, J. (2012). Relooking “Look Back”: A student's attempt at problem solving using Polya's model. International Journal of Mathematical Education in Science and Technology, 43(3), 357-369. https://doi.org/10.1080/0020739X.2011.618558

Lunenburg, F. C. (2011). Critical Thinking and Constructivism Techniques for Improving Student 
Achievement. National Forum of Teacher Education, 21(3), 1-9.

Masek, A., \& Yamin, S. (2012). The Impact of Instructional Methods on Critical Thinking: A Comparison of Problem-Based Learning and Conventional Approach in Engineering Education. ISRN Education. https://doi.org/10.5402/2012/759241

Polya, G. (2004). How To Solve It: A New Aspect of Mathematical Method (No. 246). In Princeton University Press.

Priyadi, R., Mustajab, A., Tatsar, M. Z., \& Kusairi, S. (2018). Analisis Kemampuan Berpikir Kritis Siswa SMA Kelas X MIPA dalam Pembelajaran Fisika. JPFT (Jurnal Pendidikan Fisika Tadulako Online), 6(1), 53-55. https://doi.org/10.22487/j25805924.2018.v6.i1.10020

Purwati, R., Hobri., \& Fatahillah, A. (2016). Analisis Kemampuan Berpikir Kritis Siswa Dalam Menyelesaikan Masalah Persamaan Kuadrat Pada Pembelajaranmodel Creative Problem Solving. Kadikma, 7(1), 84-93.

Romberg, T. A. (1995). Reform in school mathematics and authentic assement. New York Press.

Sanjaya, W. (2009). Strategi pembelajaran berorientasi standar proses pendidikan. Prenada.

Setiana, D. S., Santosa, R. H., Izzaty, R. E., \& Herawan, T. (2019). Developing mathematics learning tools to stimulate critical thinking. International Journal of Advanced Science and Technology, 128, 81-90. http://article.nadiapub.com/IJAST/Vol129/8.html

Wagner, T. (2014). The Global Achievement Gap. In Basic Books. Basic Books.

Wahyu, A., Wibowo, T., \& Kurniawan, H. (2019). Analisis Kemampuan Looking Back Siswa Dalam Pemecahan Masalah Matematika. Prosiding Sendika, 5(1), 81-87.

Widodo, S., Santia, I., \& Jatmiko. (2019). Analisis Kemampuan Berpikir Kritis Mahasiswa Pendidikan Matematika pada Pemecahan Masalah Analisis Real. Jurnal Pendidikan Matematika Raflesia, 4(2), 114. https://doi.org/10.24127/ajpm.v8i2.1947

Zubaedah, S. (2016). Keterampilan Abad Ke-21: Keterampilan Yang Diajarkan Melalui Pembelajaran. Jurnal Penelitian

Pendidikan. https://www.researchgate.net/publication/318013627_KETERAMPILAN_ABAD_KE21_KETERAMPILAN_YANG_DIAJARKAN_MELALUI_PEMBELAJARAN 